\title{
Rosmarinus officinalis L. Essential Oil Protects Astrocytes against Oxidative Damage
}

\author{
Abashwashi MA, Palomino OM* and Gómez-Serranillos MP \\ Department of Pharmacology, School of Pharmacy, Universidad Complutense de Madrid, Spain
}

Submission: March 13, 2017; Published: May 02, 2017

*Corresponding author: Olga M Palomino, Department of Pharmacology, School of Pharmacy, Universidad Complutense de Madrid, Plaza Ramón y Cajal s/n, 28040 Madrid, Spain, Tel: + 3491394 1767; Fax: + 339139417 26; Email: olgapalomino@farm.ucm.es

\begin{abstract}
Rosmarinus officinalis L. (Rosemary) is an aromatic species spontaneously growing in the Mediterranean area. The antioxidant ability of essential oils has led to experimental approach in neurodegenerative or cancer diseases that imply oxidative processes. The aim of this study is to assess the in vitro antioxidant and neuroprotective potentials of the essential oil from $R$. officinalis collected in Spain, using a $\mathrm{H}_{2} \mathrm{O}_{2}$-induced oxidative stress model in the astrocytoma U373-MG human cell line. Aerial parts of $R$. officinalis were collected in central Spain and essential oil obtained by Clevenger distillation. Essential oil composition was assessed by Gas Chromatography (CG). The antioxidant ability was first evaluated by the Oxygen Radical Absorbance Capacity (ORAC) and the free radical scavenging activity (DPPH) methods. Cellular viability was assessed by MTT method assay after $24 \mathrm{~h}$ pretreatment with oil in order to measure protection from $\mathrm{H}_{2} \mathrm{O}_{2}$ in astrocytes. Furthermore, the intracellular ROS formation (DCFH-DA method), Caspase-3 activity (fluorometric assay) and reduced-glutathione (GSH) levels were determined. $R$. officinalis $L$. essential oil showed in vitro antioxidant activity through the ORAC and DPPH assays. No cell toxicity was observed for concentrations ranging from $1.0-12.5 \mu \mathrm{g} / \mathrm{ml}$ essential oil. These concentrations also exerted a protective effect on astrocytes simultaneously treated with $1 \mathrm{mM} \mathrm{H}_{2} \mathrm{O}_{2}$. Oxidative damage by $1 \mathrm{mM} \mathrm{H}_{2} \mathrm{O}_{2}$ was shown as a significant decrease in GSH concentration. R. officinalis essential oil at $12.5 \mu \mathrm{g} / \mathrm{ml}$ recovered GSH levels close to control values. A slight decrease in the activation of caspase -3 previously induced by $1 \mathrm{mM} \mathrm{H}_{2} \mathrm{O}_{2}$ was also shown at $5 \mu \mathrm{g} / \mathrm{ml}$. R. officinalis essential oil protects astrocytes against oxidative damage mainly by modulating GSH levels and caspase- 3 activity.
\end{abstract}

Keywords: Rosemary; Essential oil; GC, Astrocytes; Antioxidant; ORAC; DPPH; MTT; ROS; GSH; Caspase 3

Abbreviations: GC: Gas Chromatography; ORAC: Oxygen Radical Absorbance Capacity; ROS: Reactive Oxygen Species; FR: Free Radicals; FDA: Food and Drug Administration; FEMA: Fragrance and Essence Manufacturers Association; DPPH: 2, 2-Diphenyl-1-picrylhydrazyl; FBS: Foetal Bovine Serum; DMSO: Dimethyl sulphoxide; LRI: Linear Retention Indices; DMEM: Dulbecco's Modified Eagle’s medium; FBS: Fetal Bovine Serum; DCF: Dichlorofluorescein; DCFH-DA: 2", 7'-Dichlorofluorescin Diacetate

\section{Introduction}

Medicinal plants are a great source of new active compounds and mechanisms of action to treat human diseases. Among them, the antioxidant activity is one of the main studied effects due to the relationship between oxidative stress and reactive oxygen species (ROS) and several pathologies development. Nowadays, one of the priorities in pharmacological research is the obtention of new agents capable of prevent or at least decrease the impact of these oxidation mediators at physiological level by acting on different biochemical or pharmacological targets. Oxidative reactions are physiological processes aimed to release different substances which are needed in cellular metabolism. These reactions involve the transfer of electrons and may generate compounds known as ROS, among which there are the free

radicals (FR) and oxygen derived molecules with high reactivity. Oxidative stress is defined as the imbalance between the production of free radicals and the ability of a biological system to quickly detoxify the reactive intermediates and repair the damage caused at protein, lipid and DNA levels [1]. Antioxidant compounds are defined as those which at low concentration are capable of preventing oxidative damage mediated by free radicals trough different pathways such as a direct uptake of ROS, modulation of enzyme activity or chelating metal ions $\left(\mathrm{Fe}^{+3}\right.$, $\mathrm{Cu}^{+}$), among others [2].

Rosmarinus officinalis L. (Lamiaceae), commonly known as rosemary, is an aromatic shrub spontaneously growing in the Mediterranean regions. Aerial parts and essential oil of 
Rosemary have been used in folk medicine since ancient times for the treatment of asthenia, hypotension, chronic weakness, as carminative and to improve peripheral circulation, among others. Essential oil was described for colic, nervous disorders and painful or delayed menses; also women used it for minor menstrual complaints [3]. Nowadays, traditional use in the European Union is recognized for $R$. officinalis essential oil for two different therapeutic indications: symptomatic relief of dyspepsia and mild spasmodic disorders of the gastrointestinal tract (oral use); and relief of minor muscular and articular pain and in minor peripheral circulation disorders (cutaneous use and bath additive). Rosemary leafis rich in polyphenolic compounds with antioxidant activity [4,5]. Phenolic compounds such as flavonoids and phenolic acids exert broad pharmacological effects such as antiproliferative, antitumour, antinflammatory, apoptosis-inducing and antioxidant activities which provide important health benefits related to metabolic syndrome, cancer, brain health and immune system [6]. In vitro studies previously published with rosemary show that its antioxidant properties result mainly from the phenolic diterpenes, such as carnosic acid, carnosol and rosmanol [7].

The essential oil obtained from Rosemary aerial parts shows a complex composition which varies according the plant geographic origin or phenological stage [8-12]. According to the structure of the carbon skeleton of the main constituents of the essential oil, three biogenetic types have been described: eucalyptol type (Italy, Morocco and Tunisia), camphor-borneol type (Spain) and $\alpha$-pinene-verbenone type (France, Corsica). Rosemary oil is listed as Safe by the Fragrance and Essence Manufacturers Association of the USA (FEMA) and listed for food use by the US Food and Drug Administration (FDA). In this sense, rosemary essential oil is used as a spice, flavouring and preservative agent, as oxidation is one of the main causes of chemical deterioration which could lead to rancidity, deterioration of nutritional value and even safety of foods [13].

The leaves contain 0.5 to $2.5 \%$ of a volatile oil, consisting of 0.8-6 \% esters and 8-20\% free alcohols [14]. This essential oil is a colourless or pale yellow liquid with a camphoraceous taste and contains monoterpenes, phenols, sesquiterpenes, monoterpenoid ethers, monoterpenoid ketones, monoterpernoid alcohols, and monoterpenoid esters, camphor, eucalyptol, $\alpha$-pinene, borneol [15]. Main components are 1,8-cineol (20$50 \%), \alpha$-pinene $(15-26 \%)$, camphor $(10-25 \%)$, bornyl acetate (1-5\%), borneol (1-6\%), camphene (5-10\%) and $\alpha$-terpineol $(12-24 \%)$, with variable quantities of limonene, $\beta$-pinene, $\beta$-cariophilene and myrcene [16]. Pharmacological and clinical studies with $R$. officinalis essential oil show the antimicrobial, fungicide, spasmolytic and relaxation activities, as well as its hypotensive effect [17-21] and support its use for carminative and digestive ailments such as flatulence or sensation of gastrointestinal distension. In this study, aerial parts of samples from spontaneous population of $R$. officinalis were collected in
Madrid (Central Spain), in order to assess the in vitro antioxidant and neuroprotective potentials of its essential oil, using a $\mathrm{H}_{2} \mathrm{O}_{2}$ induced oxidative stress model in the astrocytoma U373-MG human cell line.

\section{Methods \\ Plant material}

Aerial parts of samples of $R$. officinalis spontaneously growing in central Spain were harvested during flowering in May, 2014. Samples were identified by the Department of Aromatic and Medicinal Plants Research, National Institute of Agricultural and Food Technology (INIA). A voucher specimen was deposited for internal control at the INIA (Madrid, Spain). Samples were dried in an oven at $35^{\circ} \mathrm{C}$ and kept protected from light and moisture until

\section{Extraction process}

The essential oil was obtained by hydrodistillation of the dried ground material in a Clevenger-like apparatus for $2 \mathrm{~h}$ at atmospheric pressure on about $100 \mathrm{~g}$ of sample. Time was measured from the falling of the first drop of distillate. For the sample, two replications were done. The essential oil yield was evaluated gravimetrically.

\section{Reagents}

Standards of $\alpha$-pinene, camphene, $\beta$-pinene, myrcene, limonene, 1-8 cineol, $\gamma$-terpinene, $p$-cimene, bornil acetate, camphor, borneol, $\alpha$-terpineol and verbenone were purchased from Extra synthese (Genay, France). Fluorescein (3', 6'-dihydroxyspiro [isobenzofuran-1[3H], 9' [9H]-xanthen]-3-one), AAPH (2, 2'-azobis (2-amidinopropane) dihydrochloride), 2, 2-Diphenyl1-picrylhydrazyl (DPPH), Folin-Ciocalteu's phenol reagent, gentamicin, penicillin $\mathrm{G}$ and streptomycin were purchased from Sigma-Aldrich (Spain). Dulbecco's modified Eagle's medium (DMEM), RPMI1640 medium, foetal bovine serum (FBS), PBS were purchased from Gibco (Invitrogen, Paisley, UK). Dimethyl sulphoxide (DMSO), Hydrogen peroxide solution $(30 \% \mathrm{w} / \mathrm{w})$, 3-(4,5-dimethyl-2-thiazolyl)-2,5-diphenyl tetrazolium bromide (MTT), 6-hydroxy-2,5,7,8-tetramethylchromane-2-carboxylic acid (Trolox), 2,7-dichloro-dihydrofluorescein diacetate (DCFH-DA) were obtained from Sigma-Aldrich (St Louis, MO, USA).

\section{GC analysis of $\boldsymbol{R}$. officinalis essential oil}

The GC analysis was carried out with a Hewlett Packard 6890 Series instrument equipped with an FID and HP-5 capillary columns $(30 \mathrm{~m} \times 0.25 \mathrm{~mm}, 0.25 \mu \mathrm{m}$ film thickness), working with the following temperature program: $70^{\circ} \mathrm{C}$ for ten minutes and then ramp of $3^{\circ} \mathrm{C} / \mathrm{min}$ to $220^{\circ} \mathrm{C}$; injector and detector temperature, $250^{\circ} \mathrm{C}$; carrier gas nitrogen was adjusted to a flow of $2 \mathrm{ml} / \mathrm{min}$. The samples were injected using the split mode (split ratio 1:30) and an injection volume of $0.2 \mu \mathrm{L}$. Every sample was analyzed in triplicate. Identification of the components was performed by comparison of their retention times with those of pure authentic samples and by means of their linear retention 
indices (LRI) relative to the series of n-hydrocarbons.

\section{Antioxidant capacity and Oxygen scavenging activity}

ORAC assay.Sample of Trolox was mixed with fluorescein in a 96-multiwell plate and the AAPH added. AAPH was used to generate peroxyl radicals that oxidize fluorescein causing a decrease in fluorescence (excitation wavelength $485 \mathrm{~nm}$ and emission wavelength $528 \mathrm{~nm}$ ) which is measured every 4 seconds for 90 minutes at $37^{\circ} \mathrm{C}$ in a multiwell plate reader (FLUOstar OPTIMA fluorimeter, BMG LABTECH). Results calculate the relationship of the areas under the curve between blank and samples and are expressed as micromoles of Trolox equivalents per gram.

\section{DPPH assay}

The oxygen scavenging activity of the samples was determined by the DPPH assay [22] in a multiwell plate reader (FLUOstar OPTIMA fluorimeter, BMG LABTECH). Briefly, a stock solution of DPPH of $23 \mathrm{mg} / 10 \mathrm{ml} \mathrm{MeOH}$ was kept at $5^{\circ} \mathrm{C}$ until use; then increasing concentrations of each sample were added and absorbance was recorded at $715 \mathrm{~nm}$. The free radical-scavenging activity of each solution was then calculated as the percentage of inhibition and results are expressed as $\mathrm{IC}_{50}$ value, which is defined as the concentration of extract $(\mu \mathrm{g} / \mathrm{mL})$ required to scavenge $50 \%$ DPPH radicals. The lower the $\mathrm{IC}_{50}$ value is the higher antioxidant activity. Assays were done in triplicate.

\section{Cell culture}

Human astrocytoma U373 MG line was obtained from Cell Culture and Biological Resources Unit at Alcala de Henares University [23]. Cells were grown in a humidified incubator at $5 \% \mathrm{CO}_{2}$ and $95 \%$ air at $37^{\circ} \mathrm{C}$ in Dulbecco's Modified Eagle's medium (DMEM) piruvate free, from Invitrogen (Madrid, Spain), supplemented with $10 \%$ fetal bovine serum (FBS) (Biowhitaker) and $50 \mathrm{mg} / \mathrm{l}$ of each one of the following antibiotics: gentamicin, penicillin and streptomycin.

\section{Cell treatment}

Different concentrations of rosemary essential oil (0.5-250 $\mu \mathrm{M}$ ) were dissolved in DMEM and added to the cell plates for $24 \mathrm{~h}$. In order to evaluate the protective effect against an oxidative insult, culture medium was removed and cells were treated with $1 \mathrm{mM} \mathrm{H}_{2} \mathrm{O}_{2}$ for $45 \mathrm{~min}$. For all the experiments, every sample was analyzed in triplicate, with four plates for each condition.

\section{MTT assay}

Cell viability (cell growth inhibition) was determined by MTT assay (Mosmann, 1983) with some modification. Cells were incubated in 96-well plates, at density of $5 \times 10^{4}$ cells/well for $24 \mathrm{~h}$, then the cells were treated with different concentrations of the rosemary essential oil for another $24 \mathrm{~h}$. Triton X-100 $5 \%$ was used as a negative control, finally $2 \mathrm{mg} / \mathrm{ml}$ MTT was added and the plate were incubated for $1 \mathrm{~h}$ at $37^{\circ} \mathrm{C}$, then the formazan crystal formed were dissolved by adding DMSO and the absorbance was measured at $550 \mathrm{~nm}$ using Digiscan 340 microplate reader (ASYA Hitech $\mathrm{GmbH}$, Eugendorf, Austria). For all the experiments, every sample was analyzed in triplicate, with four plates for each condition.

\section{Intracellular ROS production assay}

ROS production was evaluated by the DCFH-DA assay [23] with some modification, This assay is based on the oxidation of the nonfluorescent compound 2', $7^{\prime}$-dichlorofluorescein (DCFH) into the fluorescent compound dichlorofluorescein (DCF) in presence of ROS. Cells were incubated in 96-well plate for $24 \mathrm{~h}$ and $50 \mu \mathrm{l}$ of $2 ", 7^{\prime}$-dichlorofluorescin diacetate (DCFH-DA) at a concentration of $10 \mu \mathrm{M}$ were added for $30 \mathrm{~min}$ at darkness. Then, cells were treated with different concentrations of rosemary extract and the generation of ROS was measured for $2 \mathrm{~h}$ in a microplate fluorescence reader (FLx800, Bio-Tek Instrumentation) with excitation at $480 \mathrm{~nm}$ and emission at 510 $\mathrm{nm}$.

\section{Glutathione levels and antioxidant enzymes activity}

The content of reduced glutathione (GSH) and the activity of the antioxidant enzyme catalase (CAT) were determined and results expressed in units (U) or $\mathrm{mU} / \mathrm{mg}$ protein. The GSH levels were determined according to Hissin and Hilf [24]. Determination of GSH was performed by adding $50 \mu \mathrm{L}$ of the sample to a mixture of $150 \mu \mathrm{L}$ of $0.1 \mathrm{M}$ sodium phosphate buffer ( $\mathrm{pH} 8.0$ ), and $20 \mu \mathrm{L}$ of $o$-phthaldehyde $(1 \mathrm{mg} / \mathrm{mL}$ methanol). Preparations were incubated for $15 \mathrm{~min}$ at room temperature in darkness, and fluorescence was measured at an emission wavelength of 485 $\mathrm{nm}$ and an excitation wavelength of $528 \mathrm{~nm}$ with a microplate fluorescence reader (FLx800, Bio-Tek Instrumentation).

\section{Determination of Caspase 3}

The fluorogenic caspase 3 was used for a fluorimetric assay [25]. After the hydrolytic cleavage of the coumarin derivative by thecytosolic caspase, the fluorescent product is determined using a multiwell-fluorescence reader (Bio-Tek Instruments, USA). Fluorescence was measured at $360 \mathrm{~nm}$ excitation and 480 nm emission within a microplate reader Bio-Tek FL 800.

\section{Statistical analysis}

Each experiment was carried out in triplicate. Data are expressed as Mean \pm SD values of at least three experiments. Linear correlation analysis was used to explore the relationships between the studied variables. Correlation coefficients (R) and $\mathrm{p}$ values were evaluated to judge the fit of the correlation; twosided $\mathrm{p}<0.05$ and $\mathrm{p}<0.01$ values of correlations were considered significant and highly significant, respectively. The statistical analyses were conducted using the statistical package SPSS version 22.0 for Windows (SPSS, Chicago; IL, USA).

\section{Results and Discussion}

\section{Extraction yield and CG analysis}

The yield in essential oil with respect to dry plant is high, 
with a value of $1.86 \%$. Chromatographic analysis allows the identification and quantification of thirteen compounds in one single analysis, which correspond to nearly $70 \%$ of the total components of the essential oil. The most abundant components are camphor, 1,8-cineol and myrcene [Table 1], this composition reflecting the camphor-borneol type which is predominant in the Iberian Peninsule.

Table 1: Chemical composition of essential oil of $R$. officinalis $L$. collected in Spain, by GC, according to their retention time and by means of their linear retention indices (LRI) relative to the series of n-hydrocarbons. In brief, analysis was carried out with a HP-5 capillary columns $(30 \mathrm{~m} \times 0.25 \mathrm{~mm}, 0.25 \mu \mathrm{m}$ film thickness $)$ with the following temperature program: $70^{\circ} \mathrm{C}$ for ten minutes and then ramp of $3^{\circ} \mathrm{C} / \mathrm{min}$ to $220^{\circ} \mathrm{C}$; injector and detector temperature, $250^{\circ} \mathrm{C}$; carrier gas nitrogen was adjusted to a flow of $2 \mathrm{ml} / \mathrm{min}$. Every sample was analyzed in triplicate.

\begin{tabular}{|c|c|}
\hline Compound & Percentage \\
\hline Essential oil yield & 1.86 \\
\hline$\alpha$-pinene & 6.44 \\
\hline Camphene & 5.06 \\
\hline$\beta$-pinene & 7.07 \\
\hline Myrcene & 10.15 \\
\hline Limonene & 0.78 \\
\hline 1,8 -cineol & 16.39 \\
\hline$\gamma$-terpinene & 0.94 \\
\hline p-cimene & 0.52 \\
\hline Bornylacetate & 0.26 \\
\hline Camphor & 18.15 \\
\hline Borneol & 1.7 \\
\hline$\alpha$-terpineol & 0.23 \\
\hline Verbenone & 0.49 \\
\hline
\end{tabular}

\section{In vitro antioxidant activity}

In this study, the antioxidant activity was first evaluated in $R$. officinalis essential oil by the oxygen radical absorbance capacity (ORAC) method [26]. Trolox as a water-soluble analogue of vitamin E, was chosen as a positive control in all the assays conducted in this work.Trolox is able to decrease ROS production, to prevent cytotoxicity in human cancer cell lines and to rescue cells from apoptotic death $[27,28]$. Results show an ORAC value for rosemary essential oil of $1.20 \pm 0.13 \mu \mathrm{mol}$ $\mathrm{TE} / \mathrm{mg}$ (value is mean $\pm \mathrm{SD}, \mathrm{n}=3$ ), this indicating a moderate antioxidant capacity. Then, the oxygen scavenging activity of the samples was determined by the DPPH assay

\section{Cell viability}

The direct effect of Rosemary extract on cell viability (MTT) showed no statistically significant differences on cell survival with respect to the control group (untreated cells) for concentrations between 1.0 and $12.5 \mu \mathrm{g} / \mathrm{mL}$; the lowest $(0.5 \mu \mathrm{g} /$ $\mathrm{mL})$ and the highest $(25-250 \mu \mathrm{g} / \mathrm{ml})$ concentrations induced a decrease in cell survival (Figure 1). Thus, concentrations ranging from 1.0 to $12.5 \mu \mathrm{g} / \mathrm{mL}$ were chosen for the following assays. Pretreatment of cells with doses of 1.0, 2.5, 5 and 12.5 $\mu \mathrm{g} / \mathrm{mL}$ of essential oil for $24 \mathrm{~h}$ before $\mathrm{H}_{2} \mathrm{O}_{2}$ exposure was able to significantly recover cell viability when compared to the toxic alone (Figure 1).

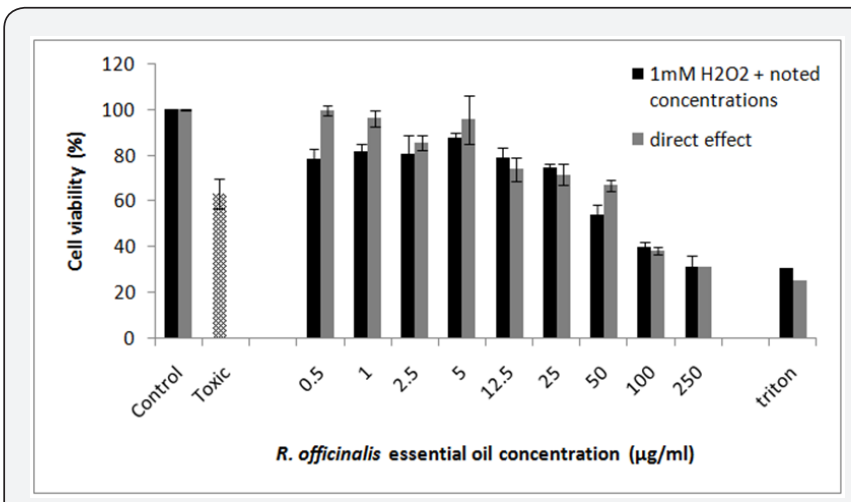

Figure 1: Effect of $R$. officinalis essential oil on cell viability compared to positive control $(0.5 \mathrm{mM}$ Trolox). Direct effect: U-373MG cells were treated with different concentrations of the compounds or essential oil for $24 \mathrm{~h}$. Protective effect: U-373MG cells were treated with different concentrations of the essential oil for $24 \mathrm{~h}$. Then cells were washed and $1 \mathrm{mM} \mathrm{H}_{2} \mathrm{O}_{2}$ was added to all the cultures except for controls for $3 \mathrm{~h}$. Cell viability is expressed as a percentage of MTT levels. Values are means \pm $\mathrm{SD}(\mathrm{n}=3,3$ replicates $){ }^{*} \mathrm{p}<0.05$.

\section{Effect on antioxidant defenses}



Figure 2: Effect of $R$. officinalis essential oil on intracellular ROS production on U373 MG cells. For the Direct effect: U-373MG cells were treated with different concentrations of the compounds or essential oil for $24 \mathrm{~h}$. For the Protective effect: U-373MG cells were treated with different concentrations of the essential oil for $24 \mathrm{~h}$. Then cells were washed and $1 \mathrm{mM} \mathrm{H}_{2} \mathrm{O}_{2}$ was added to all the cultures except for controls for $3 \mathrm{~h}$. Values are means \pm SD $(n=3,3$ replicates).

To test the effect of different concentrations on intracellular ROS levels, doses of 1.0, 2.5, 5 and $12.5 \mu \mathrm{g} / \mathrm{mL}$ of the essential oil were added and evaluated by the DCFH-DA assay (Figure 2). $\mathrm{H}_{2} \mathrm{O}_{2}$ as the oxidant insult caused an increase in ROS levels by $35 \%$ when compared to control cells. Rosemary essential oil alone did not increase ROS concentration, this indicating no cellular stress or oxidative damage which could influence the functional 
conditions of cells. Pretreatment of the cells with the essential oil previous to oxidative insult allowed ROS levels inferior to those achieved by untreated cells, although no statistically significant differences were found (Figure 2). Then, the protective effect of rosemary on GSH concentration was determined in cells treated with $1 \mathrm{mM} \mathrm{H}_{2} \mathrm{O}_{2}, 1 \mathrm{mM} \mathrm{H}_{2} \mathrm{O}_{2}$ plus noted concentrations of essential oil, or Trolox as a positive standard (Table 2). Untreated cells served as control. A depletion of intracellular GSH levels was observed when $1 \mathrm{mM} \mathrm{H}_{2} \mathrm{O}_{2}$ was added for $24 \mathrm{~h}$ to astrocytes; co-treatment with $0.5 \mathrm{mM}$ Troloxpartially recovered the depletion of GSH. Cotreatment with $12.5 \mu \mathrm{g} / \mathrm{mL}$ rosemary essential oil completely prevented the depletion of GSH levels, although the GSH recover was no statistically significant for every tested concentration.

Table 2: Protective effect of $R$. officinalis essential oilon the antioxidant defenses of U373 MG cells. GSH levels were determined in cells treated with $1 \mathrm{mM} \mathrm{H}_{2} \mathrm{O}_{2}$ or $1 \mathrm{mM} \mathrm{H}_{2} \mathrm{O}_{2}$ plus noted concentrations of the positive control $0.5 \mathrm{mM}$ Trolox or $R$. officinalis essential oil.Values are means $\pm S D, n=3$. Values are expressed as redox index $(R I)$. Different letters indicate statistically significant differences $(p<0.05)$ among groups.

\begin{tabular}{|c|c|}
\hline & GSH (nmol/mg protein) \\
\hline control & $286.61^{\mathrm{c}} \pm 15.31$ \\
\hline $1 \mathrm{mM} \mathrm{H}_{2} \mathrm{O}_{2}$ & $142.80^{\mathrm{a}} \pm 9.21$ \\
\hline $1 \mu \mathrm{g} / \mathrm{ml}+1 \mathrm{mM} \mathrm{H}_{2} \mathrm{O}_{2}$ & $145.49^{\mathrm{a}} \pm 7.32$ \\
\hline $2.5 \mu \mathrm{g} / \mathrm{ml}+1 \mathrm{mM} \mathrm{H}_{2} \mathrm{O}_{2}$ & $217.85^{\mathrm{c}} \pm 10.30$ \\
\hline $5 \mu \mathrm{g} / \mathrm{ml}+1 \mathrm{mM} \mathrm{H}_{2} \mathrm{O}_{2}$ & $152.47^{\mathrm{a}} \pm 4.61$ \\
\hline $12.5 \mu \mathrm{g} / \mathrm{ml}+1 \mathrm{mM} \mathrm{H}_{2} \mathrm{O}_{2}$ & $276.51^{\mathrm{c}} \pm 11.30$ \\
\hline $0.5 \mathrm{mM}$ Trolox & $202.54^{\mathrm{a}, \mathrm{b}} \pm 8.27$ \\
\hline
\end{tabular}

The role of reduced Glutathione (GSH) as the main non-enzymatic antioxidant defence is due to the reaction with free radicals and the repair of free radical induced damage through electrontransfer reactions. Moreover, the loss of cellular GSH seems to have an important role in apoptotic signalling [29]. Therefore, maintaining GSH concentration above a critical threshold while facing a stressful situation represents a crucial advantage for cell survival. In order to determine whether rosemary essential oil may influence cell apoptosis, the activity of the executioner caspase 3 was tested. The study on the protective effect after oxidative injury showed a decrease in caspase 3 mainly at 5 $\mu \mathrm{g} / \mathrm{mL}$ with no statistically significant differences among the assayed concentrations (Figure 3). Previous studies conducted with $R$. officinalis show strong antioxidant ability on different disorders related to oxidative stress $[4,13,30]$. Our results show that the antioxidant ability of this species may be weakly related to its essential oil, although it is not the key factor of the positive effect which could be mainly due to polyphenolic compounds. Astrocytes were chosen as cell model due to their role in neurons protection. Astrocytes are less sensitive to ischemic injury and metabolic inhibition than neurons; moreover, these cells are more resistant than neurons towards mitochondrial damage, probably due to their higher intracellular GSH and other antioxidant defenses levels.

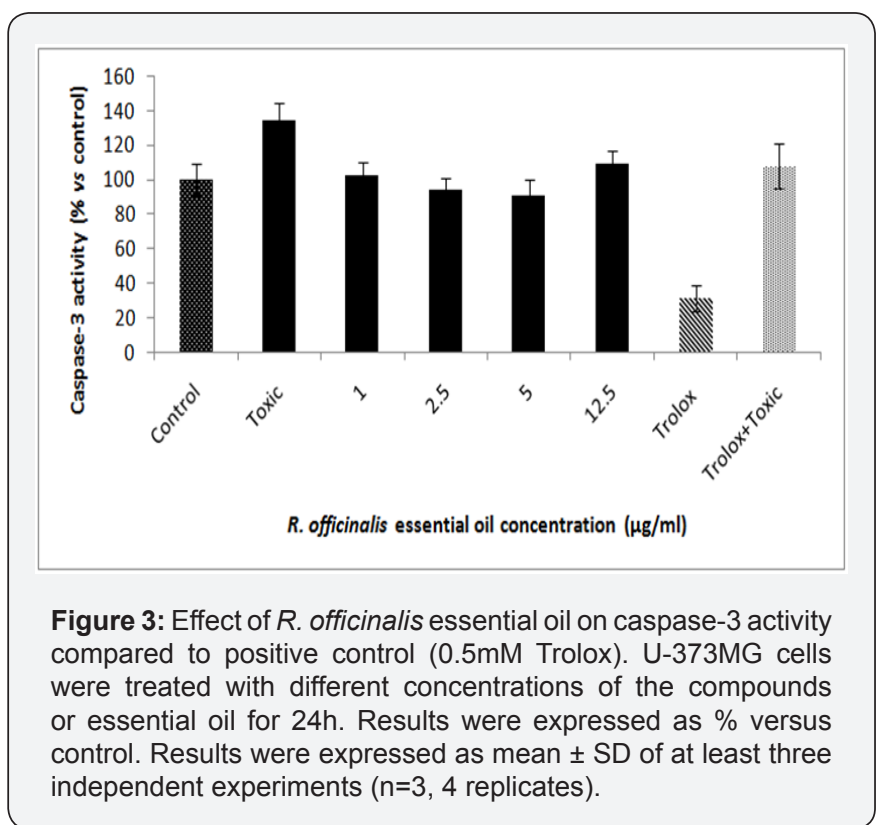

Moreover, astrocytes are able to release cystein-glycin (CysGly) as the forefather of GSH. Due to the consequences of oxidative stress in central nervous system function such as aging, brain ischemia or neurodegenerative disorders, the study of potential antioxidant agents acting at this level is one of the main research lines. In our study, $R$. officinalis essential oil effect on cell viability was assayed on the human astrocyte glioblastoma, which is known as a useful model for the study of astrocyte functions under both physiological and pathological conditions, with the aim of assessing the mechanism of action of the antioxidant ability. $R$. officinalis L. essential oil shows in vitro antioxidant activity through the ORAC and DPPH assays. It is not toxic through the MTT assay at concentrations ranging from 1.0 to $12.5 \mu \mathrm{g} / \mathrm{ml}$ and is able to protect astrocytes simultaneously treated with $1 \mathrm{mM} \mathrm{H}_{2} \mathrm{O}_{2}$. Again, oxidative damage by $1 \mathrm{mM} \mathrm{H}_{2} \mathrm{O}_{2}$ was shown as a significant decrease in GSH concentration which was completely reverted by $12.5 \mu \mathrm{g} / \mathrm{ml}$ rosemary essential oil. The study on the protective effect after oxidative injury showed a decrease in the executioner caspase 3 activity, mainly at $5 \mu \mathrm{g} /$ $\mathrm{mL}$ [31].

\section{Conclusion}

In conclusion, the results obtained in this work show a moderate in vitro antioxidant effect of $R$. officinalis essential oil, with a better profile within cell culture assays: rosemary essential oil is not toxic on the assayed cell line and exerts moderate antiradical and antioxidant activities by partially recovering GSH levels and decreasing caspase- 3 activity. These results may contribute to the knowledge of the mechanism effect, although further experiments are needed to assess and 
define the molecular mechanism of action involved in such antioxidant effect.

\section{Conflict of interest}

The authors report no declarations of interest.

\section{References}

1. Darvesh AS, Carroll RT, Bishayee A, Geldenhuys WJ, Van der Schyf C] (2010) Oxidative stress and Alzheimer's disease: dietary polyphenols as potential therapeutic agents. Expert Rev Neurother 10(5): 729-745.

2. Monica Leopoldini, Tiziana Marino, Nino Russo, Marirosa Toscano (2004) Antioxidant Properties of Phenolic Compounds: H-Atom versus Electron Transfer. Mechanism J Phys Chem A 108(22): 49164922.

3. Felter HW, Lloyd JU (1983) King's American dispensatory. Eclectic Medical Publications, Sandy, OR, USA.

4. M Abuashwashi, O Palomino, P Gómez-Serranillos (2014) Variability in the polyphenolic composition and antioxidant ability of wild Rosmarinus officinalis L. collected in Spain. Planta Medica 80(16): 1551.

5. Collins MA, Charles HP (1987) Antimicrobial activity of Carnosol and urosalic acid: two anti-oxidant constituents of Rosmarinus officinalis $L$. Food Microbiol 4(4): 311-315.

6. Gómez-Serranillos MP, Palomino OM (2012) Quercetin: Natural Sources and Health Benefits. In: Quercetin: Dietary Sources, Functions and Health Benefits. Nova Science Publishers, USA.

7. Haraguchi H, Saito T, Okamura N, Yagi A (1995) Inhibition of Lipid Peroxidation and Superoxide Generation by Diterpenoids from Rosmarinus officinalis. Planta Med 61(4): 333-336.

8. Angioni A, Barra A, Cereti E, Barile D, Coïsson JD, et al. (2004) Chemical composition, Plant genetic differences, antimicrobial and antifungal activity investigation of the essential oil of Rosmarinus officinalis $L$. J Agric Food Chem 52(11):3530-3535.

9. Abdelaziz Elamrani, Saadia Zrira, Bachir Benjilali, Mohamed Berrada (2000) A study of Moroccan rosemary oils. J Essent Oil Res 12(4): 487495.

10. Alexandre Porte, Ronoel Luiz de O Godoy, Daíse Lopes, Midori Koketsu, Sueli Limp Gonçalves, et al. (2000) Essential oil of Rosmarinus officinalis L. (rosemary) from Rio de Janeiro, Brazil. J Essent Oil Res 12(5): 577-580.

11. OM Palomino, MP Gómez-Serranillos, T Ortega, ME Carretero, F Varela, et al. (2010) Variation in the essential oil composition of Rosmarinus officinalis collected from different Spanish locations in the Andalucia region. Acta Horticulturae 860: 249-253.

12. F Varela, P Navarrete, R Cristobal, M Fanlo, R Melero, et al. (2009) Variability in the chemical composition of wild Rosmarinus officinalis L. ActaHortic 826: 167-174.

13. Vicente G, Martín D, García-Risco MR, Fornari T, Reglero G (2012) Supercritical carbon dioxide extraction of antioxidants from Rosemary (Rosmarinus officinalis) leaves for use in edible vegetable oils. J Oleo Sci 61(12): 689-697.

14. Chandler (1985) Rosemary. Clinical Edge: 40-53.
15. Fahim FA, Esmat AY, Fadel HM, Hassan KF (1999) Allied studies on the effect of Rosmarinus officinalis L. on experimental hepatotoxicity and mutagenesis. Int J Food Sci Nutr 50(6): 413-427.

16. ESCOP Monographs on the medicinal uses of plant drugs (1997) Rosmarini folium cum flore - Rosemary. European Scientific Cooperative on Phytotherapy, Fascicule 3.

17. Mahmoud B Aqel (1992) A vascular smooth muscle relaxant effect of Rosmarinus officinalis. Int J Pharmacog 30(4): 281-288.

18. Erenmemisoglu A, Saraymen R, Ustun S (1997) Effect of a Rosmarinus officinalis leave extract on plasma glucose levels in normoglycaemic and diabetic mice. Pharmazie 52(8): 645-646.

19. Fernández LF, Palomino OM, Frutos G (2013) Effectiveness of Rosmarinus officinalis essential oil as antihypotensive agent in primary hypotensive patients and its influence in Health-Related Quality of Life. J Ethnopharmacol 151(1): 509-516.

20. Panizzi L, Flamini G, Cioni PL, Morelli I (1993) Composition and antimicrobial properties of essential oils of four Mediterranean Lamiaceae. J Ethnopharm 39(3): 167-170.

21. Taddei I, Giachetti D, Taddei P, Mantovani P (1988) Spasmolytic activity of Peppermint, Sage and Rosemary essences and their major constituents. Fitoterapia 59(6): 463-468.

22. Sharma OP, Bhat TK (2009) DPPH antioxidant assay revisited. Food Chemistry 113(5): 1202-1205.

23. Mosmann T (1983) Rapid colorimetric assay for cellular growth and survival: Application to proliferation and cytotoxicity assays. J Immunol Meth 65(1-2): 55-63.

24. LeBel CP, Ischiropoulos H, Bondy SC (1992) Evaluation of the probe $2^{\prime}-7^{\prime}$-Dichlorofluorescin as an indicator of reactive oxygen species formation and oxidative stress. Chem Res Toxicol 5(2): 227-231.

25. Hissin PJ, Hilf R (1976) A fluorometric method for the determination of oxidizes and reduced glutathione in tissues. Anal Biochem 74(1): 214-226.

26. Marks N, Berg MJ, Guidotti A, Saito M (1998) Activation of caspase-3 and apoptosis in cerebellar granule cells. J Neurosci Res 52(3): 334341.

27. Dávalos A, Gomez-Cordoves C, Bartolome B (2004) Extending applicability of the oxygen radical absorbance capacity (ORACfluorescein) assay. J Agric Food Chem 52(1): 48-54.

28. Kello M, Drutovic D, Chripkova M, Pilatova M, Budovska M, et al. (2014) ROS-Dependent Antiproliferative Effect of Brassinin Derivative Homobrassinin in Human Colorectal Cancer $\mathrm{Caco}_{2}$ Cells. Molecul 19(8): 10877-10897.

29. Schoeneberger H, Belz K, Schenk B, Fulda S (2014) Impairment of antioxidant defense via glutathione depletion sensitizes acute lymphoblastic leukemia cells for Smac mimetic-induced cell death. Oncogene 34(31): 4032-4043.

30. Martín MA, Ramos S, Mateos R, Marais J, Bravo L, Khoo C, Goya L (2015) Chemical characterization and chemo-protective activity of cranberry phenolic extracts in a model cell culture. Response of the antioxidant defences and regulation of signaling pathways. Food Res Int 71: 68-82.

31. Porres M, Gómez-Serranillos MP, Carretero ME (2010) Actividad neuroprotectora del aceite esencial de Salvia lavandulifolia Vahl. Ars Pharmaceutica 51(3): 657-675. 
Your next submission with Juniper Publishers will reach you the below assets

- Quality Editorial service

- Swift Peer Review

- Reprints availability

- E-prints Service

- Manuscript Podcast for convenient understanding

- Global attainment for your research

- Manuscript accessibility in different formats ( Pdf, E-pub, Full Text, Audio)

- Unceasing customer service

Track the below URL for one-step submission https://juniperpublishers.com/online-submission.php 